Article

\title{
In the Realm of Rain Gods: A Contextual Survey of Rock Art across the Northern Maya Lowlands
}

\author{
Dominique Rissolo \\ Cultural Heritage Engineering Initiative, Qualcomm Institute, University of California, San Diego, CA 92093, \\ USA; drissolo@ucsd.edu
}

Received: 30 August 2020; Accepted: 21 September 2020; Published: 27 September 2020

\begin{abstract}
Regional rock art studies have provided insight into the role of caves in Maya ideology and worldview. In addition to the content of the imagery itself, the placement or siting of rock art with respect to natural and cultural features within the cave environment can reveal much about the function and meaning of cave use practices. This comparative analysis of rock art emphasizes contextual considerations with a discussion on the spatial and symbolic relationships between images in individual caves. Rock art in the northern Maya lowlands is commonly associated with watery areas and pathways leading to pools in caves. Across the northern Yucatan Peninsula, watery caves witnessed the rites and rituals of religious practitioners who appealed to the rain gods. Rock art scenes throughout this region were often devised and positioned in ways that reveal or are consistent with this unique and pervasive emphasis on rain and agricultural fertility in religious practice.
\end{abstract}

Keywords: Maya; rock art; Yucatan Peninsula; caves

\section{Introduction}

Previous studies regarding inter-regional variability within the corpus of Maya cave art [1-3] focus primarily on the style, age, content, or technical characteristics of the imagery rather than its particular location within the caves themselves. This paper presents a comparative analysis of rock art emphasizing contextual data, which integrates cave morphology and image placement with a discussion on the spatial and symbolic relationships between images in individual caves. By examining the contexts of the most common and broadly shared images, such as simple frontal faces, patterns pertaining to these relationships can be evaluated independent of who or what is being depicted. This approach reveals marked regional patterning and inter-regional differences within the corpus, which relate to function and meaning, and will serve to complement other innovative approaches like that advanced by Stone [3].

Rock art in the northern Maya lowlands (Figure 1) is commonly associated with watery areas and pathways leading to pools, which are often located within caves and cenotes. A discussion of this region will focus on simple faces, rain imagery, and sexual imagery, as well as art found within chultunob (human-made cisterns). Though sometimes similar in content to their southern counterparts, rock art scenes across the relatively dry karstic expanse of the northern Yucatan Peninsula are often sited or positioned in ways that reveal or are consistent with the unique and pervasive emphasis on rain and agricultural fertility in religious practice. 


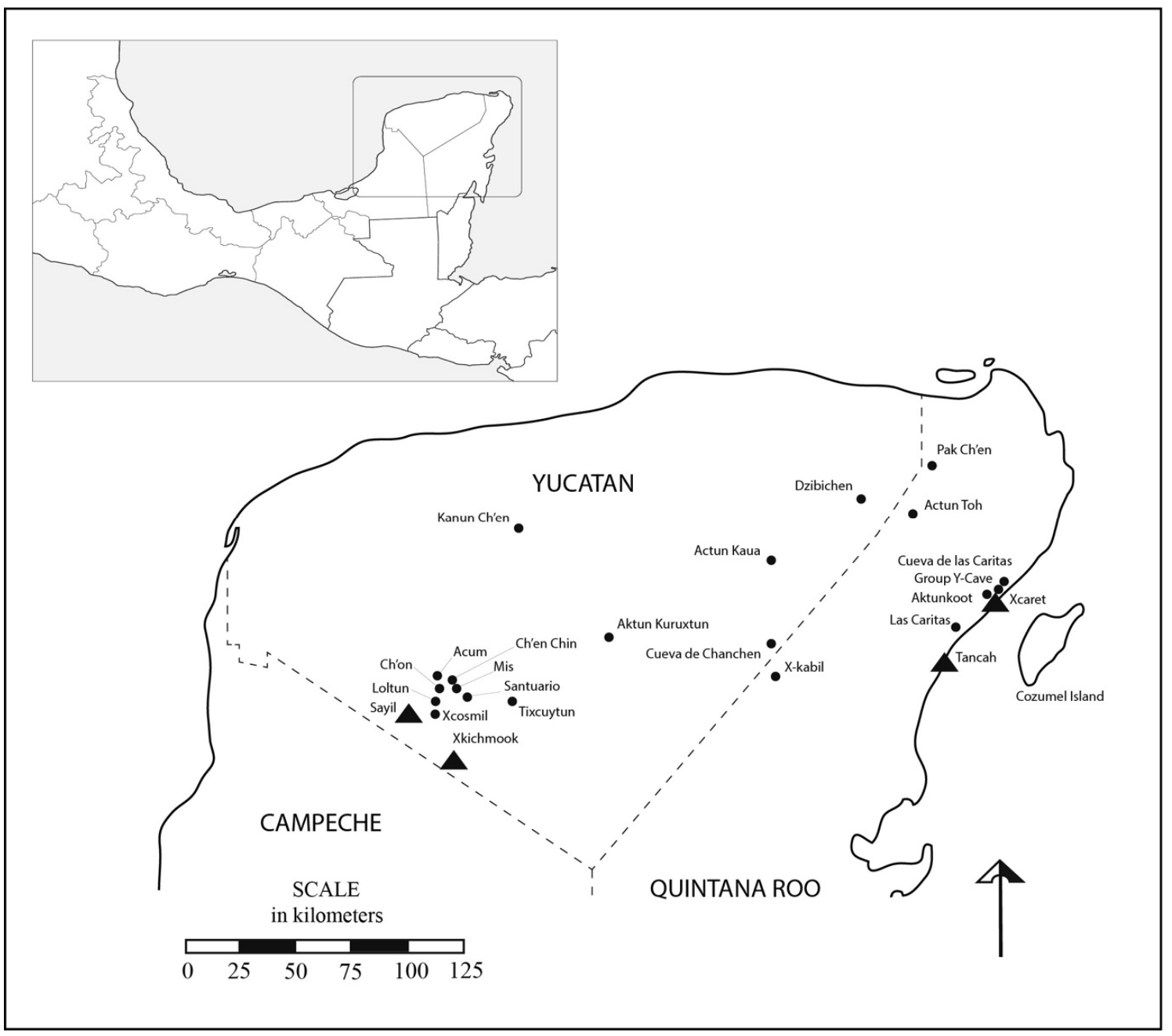

Figure 1. Map of the northern Maya lowlands indicating approximate locations of rock art sites frequently referenced in the text.

Much like its enigmatic subsurface landscape, the rock art of Yucatan and Quintana Roo is diverse in form yet exhibits a certain degree of intra-regional homogeneity. Perhaps the best known of the northern rock art traditions is that of the painted caves of the Puuc Hills. Images that reflect relatively high levels of artistic sophistication and ideological literacy can be found in Loltún [2-5], Actun Ch'on [2,3,5,6], Acum [2,3,7], Tixcuytún [2,3,8], and Aktun Santuario [9]. Stone [3] refers to the combination of shared traits in these painted images as the "Sierrita de Ticul" style in her analysis of regional variation in cave art across the wider Maya area. One notable theme is death imagery, and a number of paintings depict scenes of elite activity as well as identifiable symbols, faint or incomplete glyphs, and glyph-like elements [2,3].

According to Stone [3] (pp. 33-34), the broader tradition of Maya painted cave art is consistent with the advanced skills and knowledge of Maya artistic specialists. She suggests that in caves where both painted and less elegant carved images exist, their co-occurrence might be the result of different chronological and social factors [3] (p. 37). Like the simple clay and charcoal drawings also found in Yucatecan caves, such as Actun Kaua [10], Cueva Xcosmil [11], and Dzibichen [2] (pp. 74-86), the comparatively crude carved images likely represent a more vernacular tradition, as described by Stone [3] (p. 41). This study draws more upon the latter category of rock art-the symbolic content of its imagery often inherently problematic and resistant to compelling interpretations-and examines the caves that surround it. 


\section{Frontal Faces}

Simple carved or pecked faces have been found in caves and rock shelters throughout Mesoamerica. These images can be described as both ubiquitous and idiosyncratic. Though there are subtle regional similarities and differences, these likely reflect stylistic variation (combined with individualistic expression), as opposed to strict symbolic convention or intent. Rather than attempt to interpret the content of the faces themselves, I propose that their significance is largely a matter of context. Indeed, a great number of these images appear to be related to watery areas within caves and therefore differ further from the Sierrita de Ticul rock art described above.

Among the more well-known groups of carved faces in the northern lowlands are those found in Cueva Xcosmil [11] (Figure 2a). Here, as in many caves, face shapes range from circular to ovoid, triangular, or flat-topped, and can often exhibit simian or skull-like characteristics. Strecker [11] (p. 17) notes that drip-water in Cueva Xcosmil accumulates in natural depressions in the floor of the small, single-chamber cave. He suggests that rock art in Cueva Xcosmil and Cueva Ehbis is related to the caves' watery features [11] (p. 20). In the Calcehtok area, at least two caves are reported to contain both haltunob, for the collection of drip-water, and simple carved faces [12,13] (p. 25).

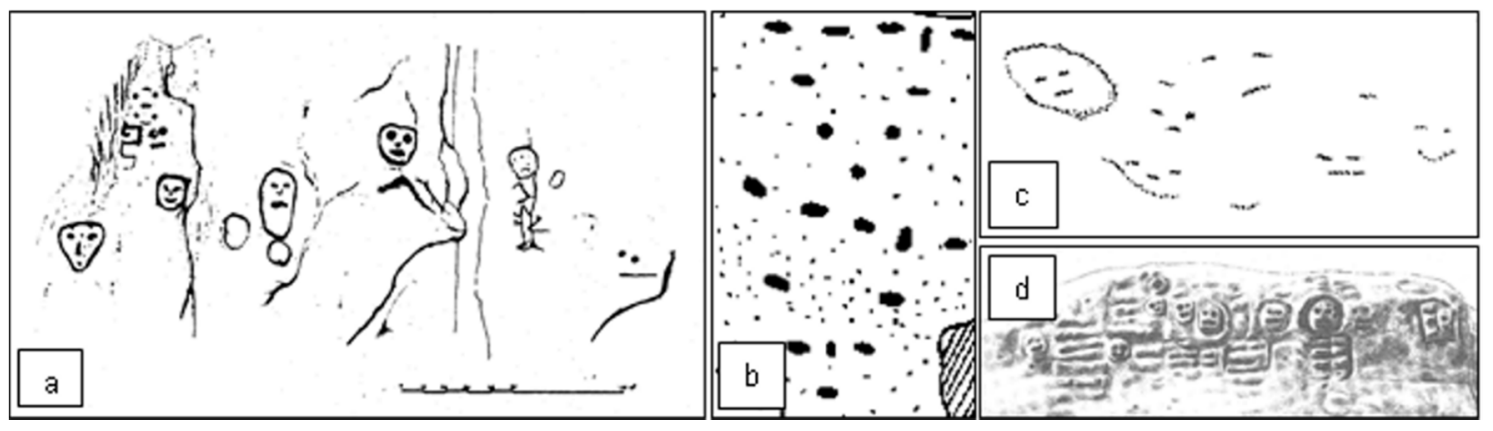

Figure 2. Simple carved or pecked faces: (a) Cueva Xcosmil, petroglyph no. 11, north portion, after [11] (figure 10); (b) Aktún Ch'en Chin, panels IV and V, adapted from [14] (Figure 7); (c) Pak Ch'en, panel F, adapted from [15] (Figure 4.5.16); (d) Tancah Cenote, adapted from [16] (Figure 119).

A more direct relationship between carved faces and water is apparent in a number of caves in the northern lowlands. During a survey of caves and cenotes in northern Quintana Roo, Rissolo [15,17] noted the co-occurrence of rock art with pathways and stairways that lead to pools of water. In Actun Toh, a stairway leads from the top of a pyramidal structure within the cave (located beneath a vertical entrance shaft) and descends into a small chamber [15] (pp. 37-39). At the opening of this chamber, the stairway passes below a panel of five carved faces, and ultimately arrives at a small pool. Just over the nearby border, in Yucatán, a similar spatial arrangement is present in Xca'ca'ch'en. Here, three faces mark a route, delineated by paths and stairways, which leads to the pool within the cave.

The most notable expression of this pattern is found in Pak Ch'en. Among the more sophisticated and diagnostic images in the cave, a gallery of numerous carved and pecked faces follows the curving path as it descends to the pool below [15] (pp. 62-71). The larger portion of the cave, which is not associated with this watery route, is entirely devoid of such spatial marking. This seems to be the case as well in Aktún Ch'en Chin [14] (pp. 40-42). In Aktún Ch'en Chin, carved images mark the entrance of the cave itself, while a panel of faces is located near the remote cave pool [14] (Figure 70). Several of these faces consist of nothing more than deeply pecked orbits, mouths, and sometimes noses (Figure 2b). Similar faces are found directly above the pool in Pak Ch'en [15] (p. 68) (Figure 2c). I would argue that the meaning of faces rendered in such a crude manner has more to do with the desire or need to invoke them than with their stylistic attributes.

Martos López [18-21] has recorded numerous carved faces associated with stairways and pools in Aktunkoot and Cueva de las Caritas, located near the coastal site of Xcaret. Located further to the south, the cenote at Tancah is unique in that the stairway itself, which faces the water, has been both 
hewn into the bedrock and festooned with numerous carved images. First reported by Lothrop [22], the cenote was later visited by Robina [23], who published descriptions and drawings of the rock art. The illustration from Miller [16] (figure 119) shows faces and glyph-like elements carved into the risers of the stairs. Miller [16] (p. 87) identifies the calendrical and celestial Lamat glyph and 1 Ahau and suggests that they signify Venus rising out of the darkness, which is symbolically represented by the dark water of the cenote. Though I find this interpretation to be speculative, this carved stairway certainly befits a watery place [24]. Houston [25] (p. 360) suggests that these steps might be related to maquetas, or models of actual stairways or terraces, over which the symbolic flow of water was controlled or observed. Such ritualized channeling of water appears to have been common throughout Mesoamerica, for example at Chalcatzingo [26,27] (pp. 148-153). Examples of such maquetas can be found in Loltún [4] (plates IV and V).

The small faces in Tancah Cenote, and the ladder- or stair-like elements below them, are of particular interest (Figure 2d). Uc González and Canche Mazanero [13] (Figure 4) recorded an image nearly identical to those from Tancah. These escalerita motifs (without the associated faces) are present in the caves of Ehbis, Xcosmil, and Cahum [11] and in caves reported by Martos López [18,20]. Based on their locations within Ehbis and Aktún Ch'en Chin, Bonor Villarejo and Sánchez y Pinto [14] (pp. 48-49) suggest that these representations of ladders serve as directional indicators for visitors to the caves. The escaleritas and associated faces of Tancah Cenote appear to be more enigmatic and could possibly be related to the symbolic trickling of water.

In a cave informally known as Las Caritas (the faces), a number of natural and cultural features come together in a manner that embodies the rock art-cave pool complex one might describe as characteristic of the northern lowlands. With Fred Devos, Rissolo [28] documented a series of simple carved faces, handprint pictographs, a masonry shrine, and an altar in this extensive water-filled cave in Quintana Roo. Each of the faces appear on dripstone or flowstone formations. This arrangement is also present in a watery cave known as Socorro [29]. Adjacent to an embellished drapery formation in Las Caritas (Figure 3a) is a haltun (or basin) carved into a flowstone mound (Figure 3b) similar to those found in Cueva de Chanchen-a cave in Yucatan with a circuitous path to a pool of water [21] (pp. 191-192). To collect drip water in a cave with pools is telling of the ritual intent. It is here that zuhuy ha (virgin water) might be procured. Across the ceiling of the cave, adjacent to the expansive pool, are a series of positive red handprints. Like simple carved faces, they are somewhat enigmatic and have been the subject of some speculation (in terms of possible meaning). The cave of Acum, for example, contains 79 positive and 56 negative handprints [30] (Table I). Handprints have also been recorded at Tixcuytún [8], Aktun Santuario [9], Kanun Ch'en [31], and Cueva de X-kabil [32] (Figure 29), among others.

Architectural features have been documented in caves throughout the Maya area [33]. Along the central coastal region of Quintana Roo, shrines or miniature temples-constructed in the Late Postclassic East Coast style - can be found in several of the region's caves [28,34,35]. For both cave shrines and altars, the stylistic correspondence to religious architecture at nearby surface sites can be remarkable, and their presence in caves such as Las Caritas provide clear evidence of ritual practices in these watery subterranean environments [34,35]. Within the broad entrance chamber of Las Caritas is a partially collapsed shrine constructed around or slightly behind a large stalagmite [28]. Fragments of a Postclassic Chaak effigy incense burner were found nearby. Across a portion of the cave pool is an altar—with terraced sides - also enclosing a stalagmite [28] (Figure 4). 


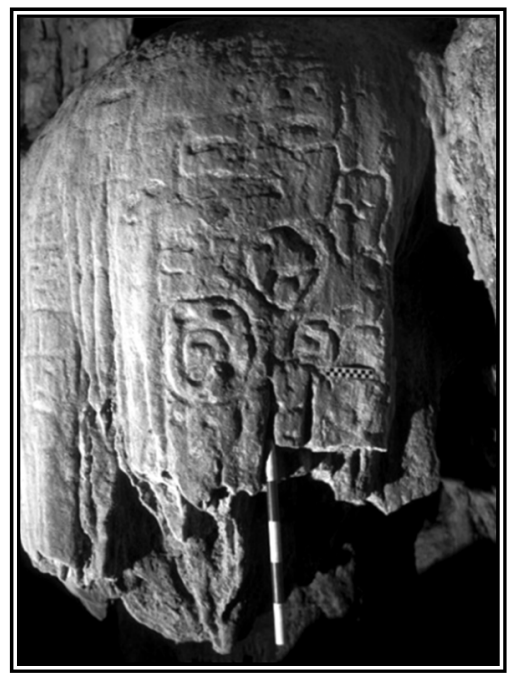

(a)

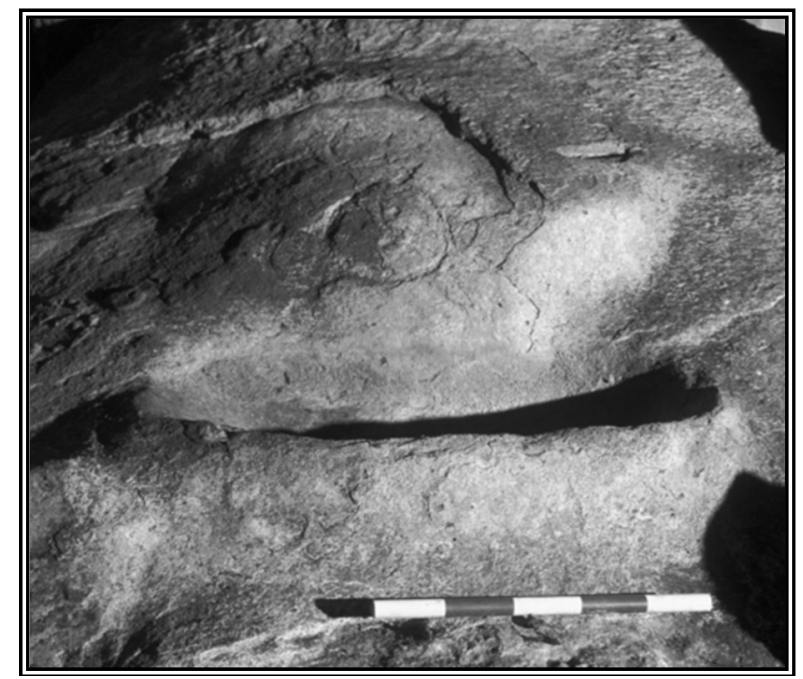

(b)

Figure 3. Cueva de las Caritas, Quintana Roo: (a) Drapery formation with carved and pecked faces (photo by D. Rissolo); (b) carved haltun-like dripwater catchment basin with circular "proto-face" (photo by D. Rissolo).

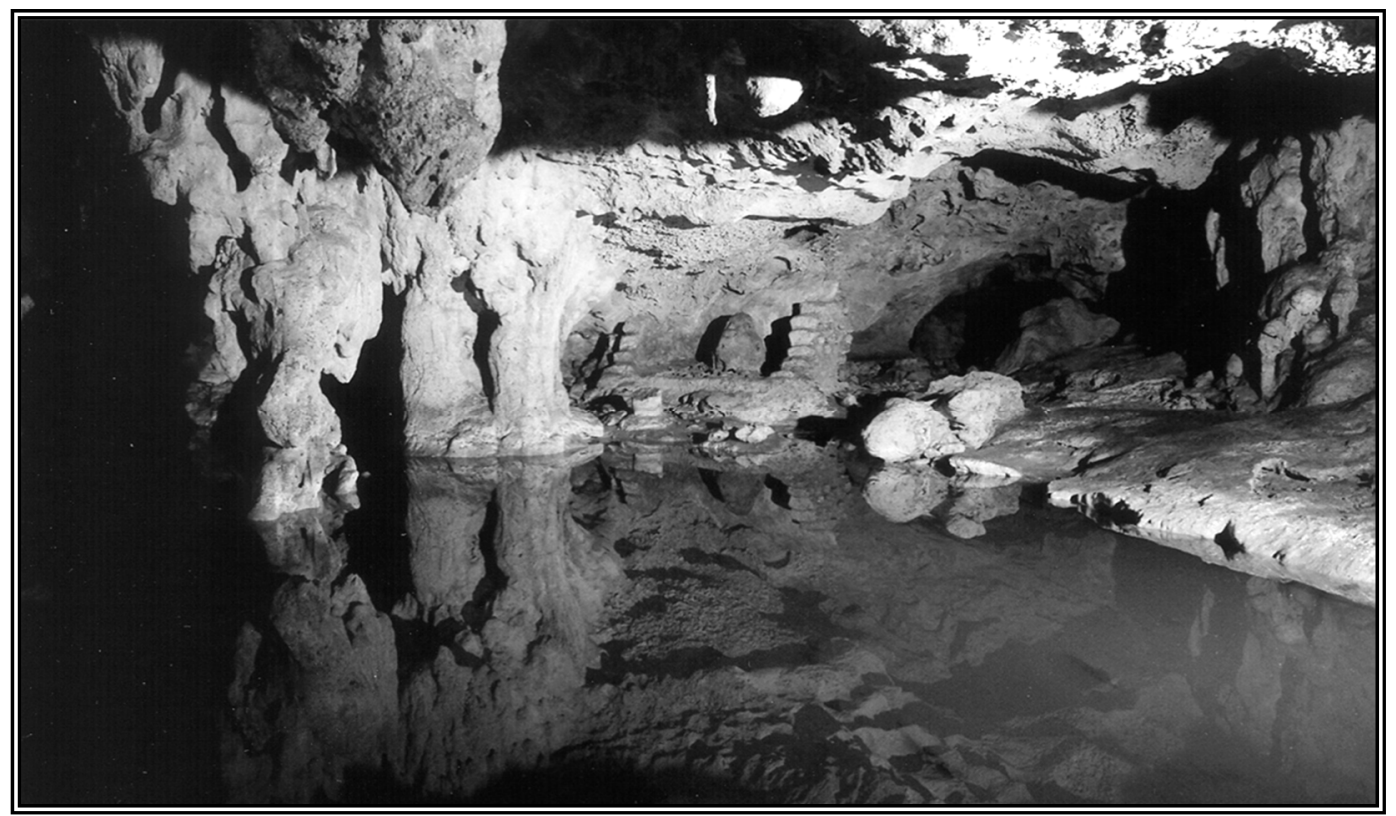

Figure 4. Speleothem altar at edge of pool in Cueva de las Caritas (photo by D. Rissolo).

Ritual cave use during the Postclassic (ca. AD 1200 until the colonial period), particularly along the central coastal region, is evidenced not only by characteristic shrines and altars and effigy censers of the Chen Mul type, but also by certain petroglyphs (like those described below in Pak Ch'en), which clearly correspond to this late period. Nevertheless, by their very nature, simple carved faces can be difficult (if not impossible) to date. Rock art panels-and indeed many surfaces within caves-can effectively serve as palimpsests. It is interesting to note, however, that caves can possess and preserve material culture spanning the earliest and latest components within a given region. In Actun Toh [15] (pp. 37-55)—where a cluster of carved faces flank a stairwell leading to an ephemeral pool within the cave - a robust and diverse assemblage of exceptionally early pottery (Middle Preclassic; ca 700 BC-150 BC) was recovered. Like many caves with rock art in the region (including Pak Ch'en), the pottery deposited within may span well over a millennium. 
The very presence of simple carved faces in a cave mark it as one that has been appropriated for a specific use, which was likely done in accordance with established criteria (e.g., the presence of water). Similarly, the location of those images within the cave itself reveals the value placed on certain features or areas within this underground space. Perhaps the most compelling interpretation of the role of these simple faces comes from a regional study of caves in central Yucatan by Donald Slater [36]. He suggests that these faces essentially served to "animate caves" [36] (p. 593). Indeed, the play of light and shadow-accentuated by the flickering torches of more ancient visitors-would have made for a profound experience [36]. Slater posits the notion of such faces as "spiritual entities" [36] (p. 592). This has significant implications (particularly with respect to contextually focused studies), since it shifts our attention away from the act of depiction, to that of channeling or conjuring. In a subtle repositioning of Slater's proposal, the faces are not only "meant to serve as anthropomorphic representations of the notions of ch'ulel [lifeforce] and the animate earth" [36] (p. 593); the very human act of carving these faces could be tied to activating this lifeforce.

It should be noted that the Petroglyph Chamber in Aktun Kuruxtun, studied by Slater [36] (pp. 576-621), does not contain a pool or provide access to water, though it is prone to flooding events (pp. 576-577). Simple frontal faces, therefore, are not exclusive to watery caves. However, their deliberate siting or positioning relative to pathways to water is no less meaningful from the experiential perspective described above.

Indeed, the frontal faces of Actun Kuruxtun represent a rare exception to the path-to-pool pattern characteristic of the northern Maya lowlands. However, in the caves of Belize, to the south, simple carved frontal faces are located near the entrances of dry caves and are therefore not spatially associated with pools of water. Notable examples of this dissimilar arrangement are Actun K'aana, where faces carved into speleothems flank the entrance path into the cave [37] (p. 107; Figure 5.4.8), and Actun Uayazba Kab [38,39] (p. 119), where faces and other carved elements adorn an entrance chamber. In Belize, it appears as if faces were meant to be viewed from entrance paths - so that their gaze met with visitors as they ventured into the darkness [40] — rather than positioned relative to pools or access to water sources in caves.

\section{Rain Imagery}

A wide range of motifs and figures are believed to be associated with rain, and I draw from several examples found within the northern rock art corpus. On the walls of a cave near the community of X-kabil, Quintana Roo, are a number of positive handprints and painted S-scrolls [32] (pp. 99-100) (Figure 5a). This cave was investigated by Miguel Astor-Aguilera, who was told by local men that it had been used for the collection of zuhuy ha, or virgin water [41]. Houston and Stuart [42] have read the S-scroll glyph T632 as muyal or "cloud." This reading was independently confirmed by Stone [43]. A painted S-scroll was also reported in Cueva de Chanchen in Yucatan [21] (plates 230 and 321).

Stone [43] articulates the numerous interrelated meanings or associations of this symbol, among which are clouds and Chaak, the god of rain. Both Stone [43] (figure 8) and Reilly [45] (Figure 6b) describe a scene from the Dresden Codex [44] (p. 146) in which two Chaaks sit beneath S-Scrolls, and one, like a cloud, issues rain (Figure 5b). Reilly [45] demonstrates that the S-scroll (or Lazy-S) has been associated with clouds and rain as early as the Middle Formative, and cites the discovery of Monument 31 at Chalcatzingo, where this motif is used in other watery scenes [46], including Monument 1 (also known as "El Rey"). In the cave at X-kabil, one of the S-scrolls is surrounded by dots and is positioned above an anthropomorphic figure. Though the T632 is often surrounded by dots, this particular image brings to mind raindrops. Depictions of similar "bunches" of raindrops can be seen in the Middle Formative rock shelter paintings of Cacahuaziqui in Guerrero [47] (Figures 3, 4). I argue that this "stick figure" in the cave at X-kabil is in fact a depiction of the Maya god of rain and lightning, Chaak.

Animals associated with rain or water have been reported in caves. Strecker [11] (p. 20) mentions a possible carved toad in Xcosmil, and Martos López [19,20] describes a stylized fish carved into a 
dripstone column in Aktunkoot. Interestingly, a number of water creatures, such as toads and turtles, were modeled in stucco on the interiors of chultunob in the Puuc region [48-51] as well as carved into a water basin located inside a Formative pyramid at Totimehuacan, Puebla [52,53].

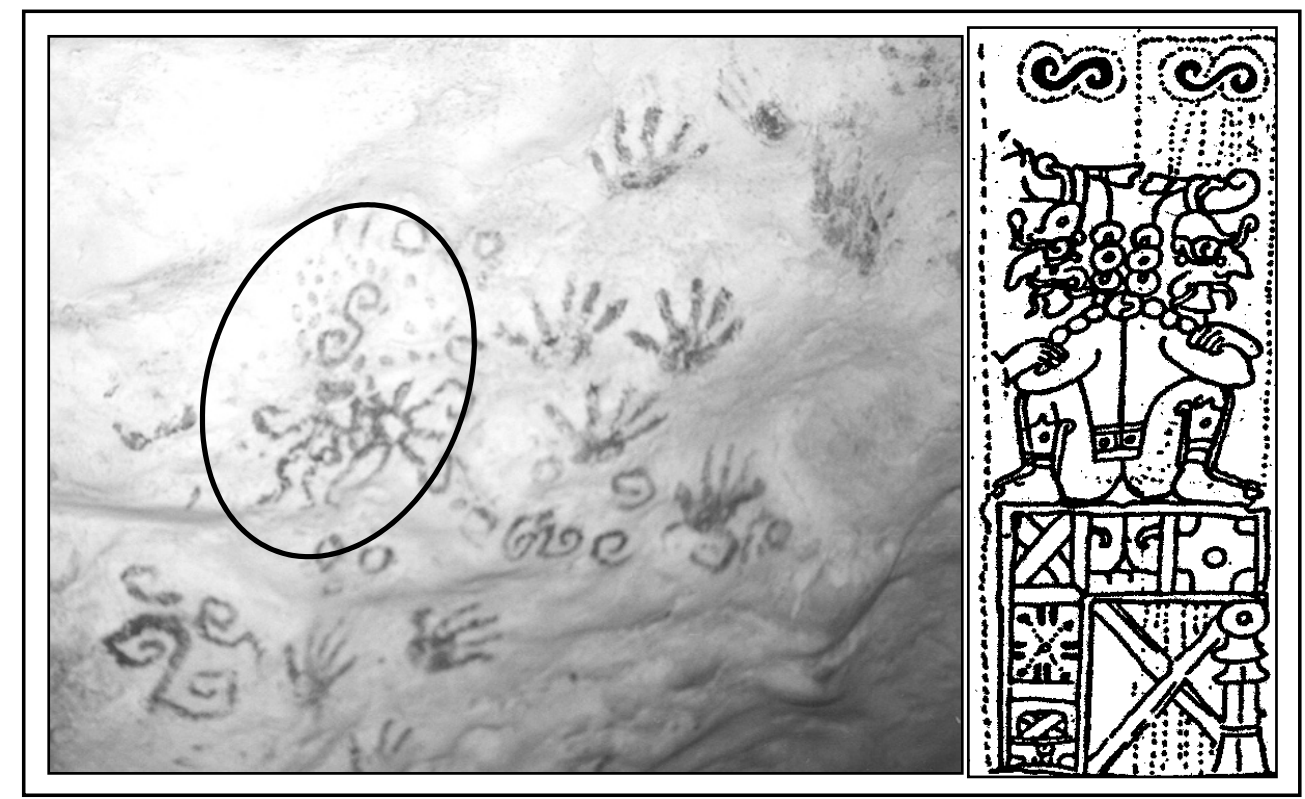

(a)

(b)

Figure 5. Depictions of clouds and rain: (a) the cave at X-kabil, Quintana Roo, note circled figure (photo by Miguel Astor-Aguilera); (b) Page 68a, the Dresden Codex, after [44].

Though not explicitly identified as such, the anthropomorphic figure recorded by Tec Pool in Kanun Ch'en [31] (Figure 8) appears to be that of the Maize God. In the cave of Tixcuytún, Barrera Rubio and Peraza Lope [8] (pp. 50-53, photo 15) suggest that a pictograph of a face naturalistically rendered in profile might represent God B (Chaak). Themes of rain, agricultural fertility, and sacredness are indeed interconnected.

Depictions of rain deities in caves are among the most overt examples of water-related imagery. In Pak Ch'en [15] (pp. 62-71), one such image is found along the gallery that follows the path to the pool (Figure 6a). This figure appears to exhibit both Chaak- and Tlaloc-like features, which Taube describes as a common Late Postclassic development in rain god imagery [54] (pp. 133-136). Examples of similar figures with fanged maws and non-goggled eyes were found at Santa Rita and Mayflower, Belize [54] (Figures 73a,f). A frontal face in Cueva Mis near Oxkutzkab (Figure 6b) bears a striking resemblance to the rain-god face in Pak Ch'en [55] (Figure 19). However, Strecker and Stone suggest that the petroglyph in Mis may represents a "life and death mask" [55] (p. 72).

Directly across the pathway from the rain-god face in Pak Ch'en is a profile carved into a large boulder (Figure 7). The deity depicted here has been identified by Karl Taube as God C [56]. The shape of the forehead, nose, and mouth are quite distinct and bear a strong resemblance to depictions of God C in the Dresden and Madrid Codices [15] (pp. 68-69). A description of God C by Taube [50] (p. 30) suggests that invoking such a deity in Pak Ch'en is consistent with marking or designating this watery cave as a sacred place. Interestingly, a frontal face etched and pecked into the same boulder might represent God C as well [15] (pp. 69-70) (Figure 8a). Present is the flat forehead and distinctive nose (though lacking are the lips and mouth characteristic of codical depictions of God C in profile). A similar visage was documented by Martos López in Aktunkoot in Quintana Roo [20] (Figure 59) (Figure $8 b$ ). Here, the apparent ear ornament (as present in codical depictions and in the profile of God $\mathrm{C}$ in Pak Ch'en) seems to support such an interpretation. 


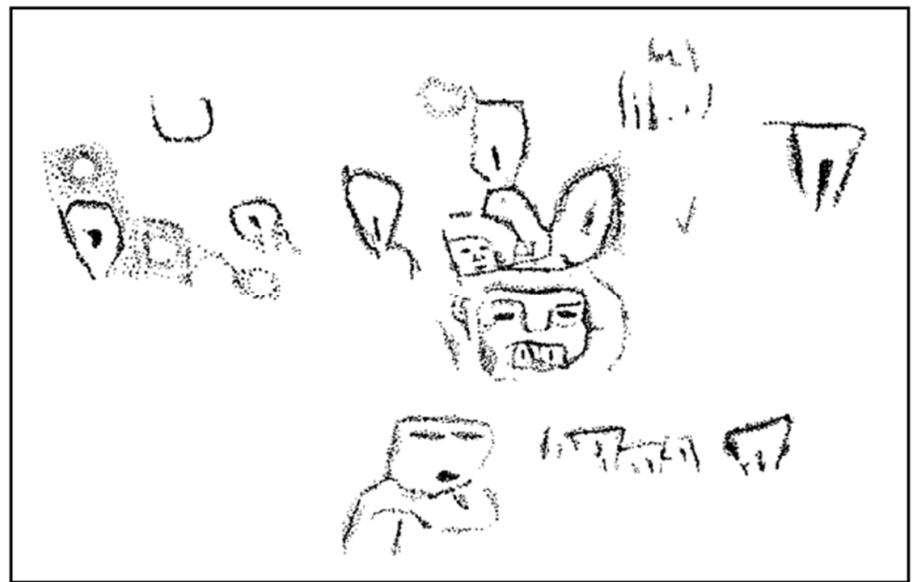

(a)

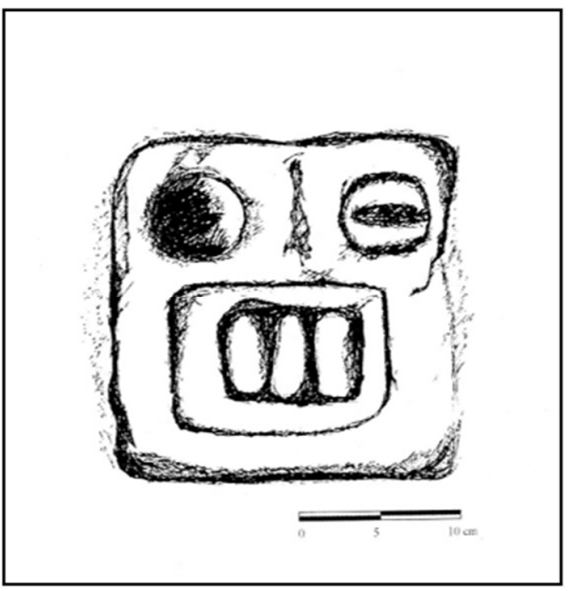

(b)

Figure 6. (a) Vulva motifs surrounding a possible rain god image in Pak Ch'en, Quintana Roo, after [15] (Figure 4.5.5); (b) face in Cueva Mis, Yucatan, after [55] (Figure 19).

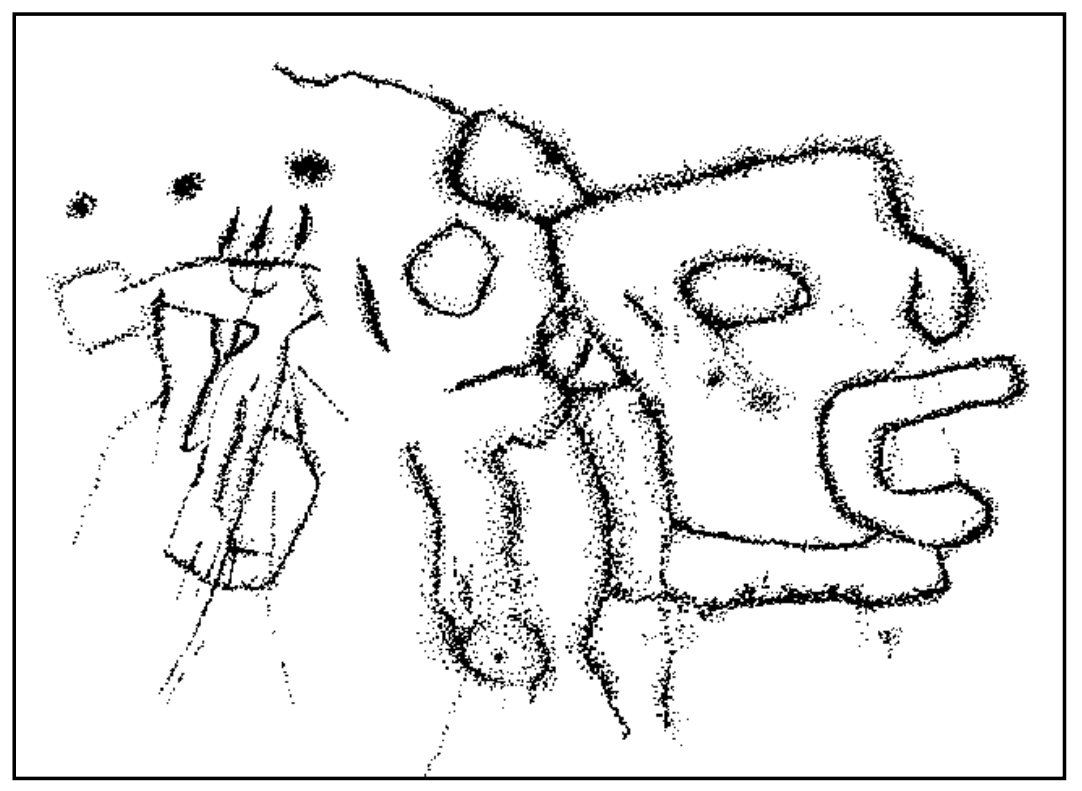

Figure 7. Petroglyph of God C in Pak Ch'en, after [15] (Figure 4.5.17).

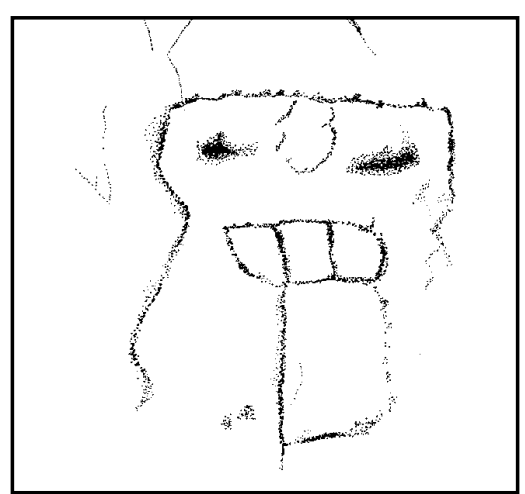

(a)

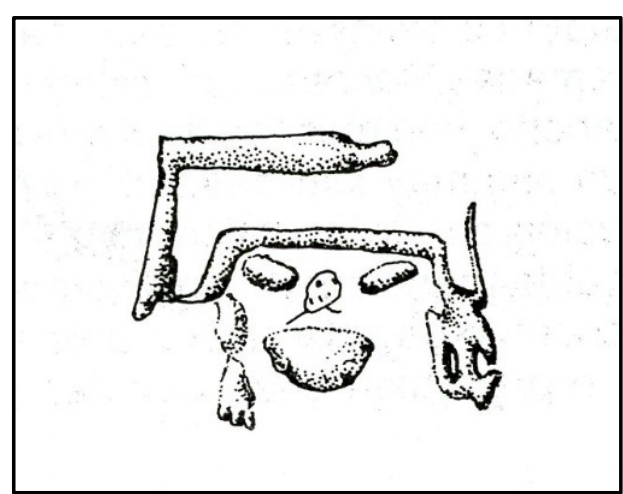

(b)

Figure 8. Possible frontal depictions of God C: (a) Pak Ch'en, after [15] (Figure 4.5.19); (b) Aktunkoot, after [20] (Figure 59). 
The general morphology or layout of Pak Ch'en is quite similar to that of Dzibichen (Figures 9 and 10)-including the presence of a stairway and small pool and a series of drawings [2] (pp. 74-86). The rock art panel in Dzibichen [2] (Figures 4-68) contains, among other images, vulva motifs and a codex-style depiction of the Yucatecan rain god Chaak [2] (p. 77). One such depiction of Chaak was also identified in Cueva de Tixcuytún [8] (photograph 15). In Dzibichen, Stone [2] points-out the figure's close association with lightning serpents, also drawn on the cave wall. Rather than serpents, vulva motifs surround the rain-god figure in Pak Ch'en (Figure 6a), yet an equally powerful statement of water and fertility appears to have been made by the cave artists. I discuss these depictions of female genitalia in more detail below.

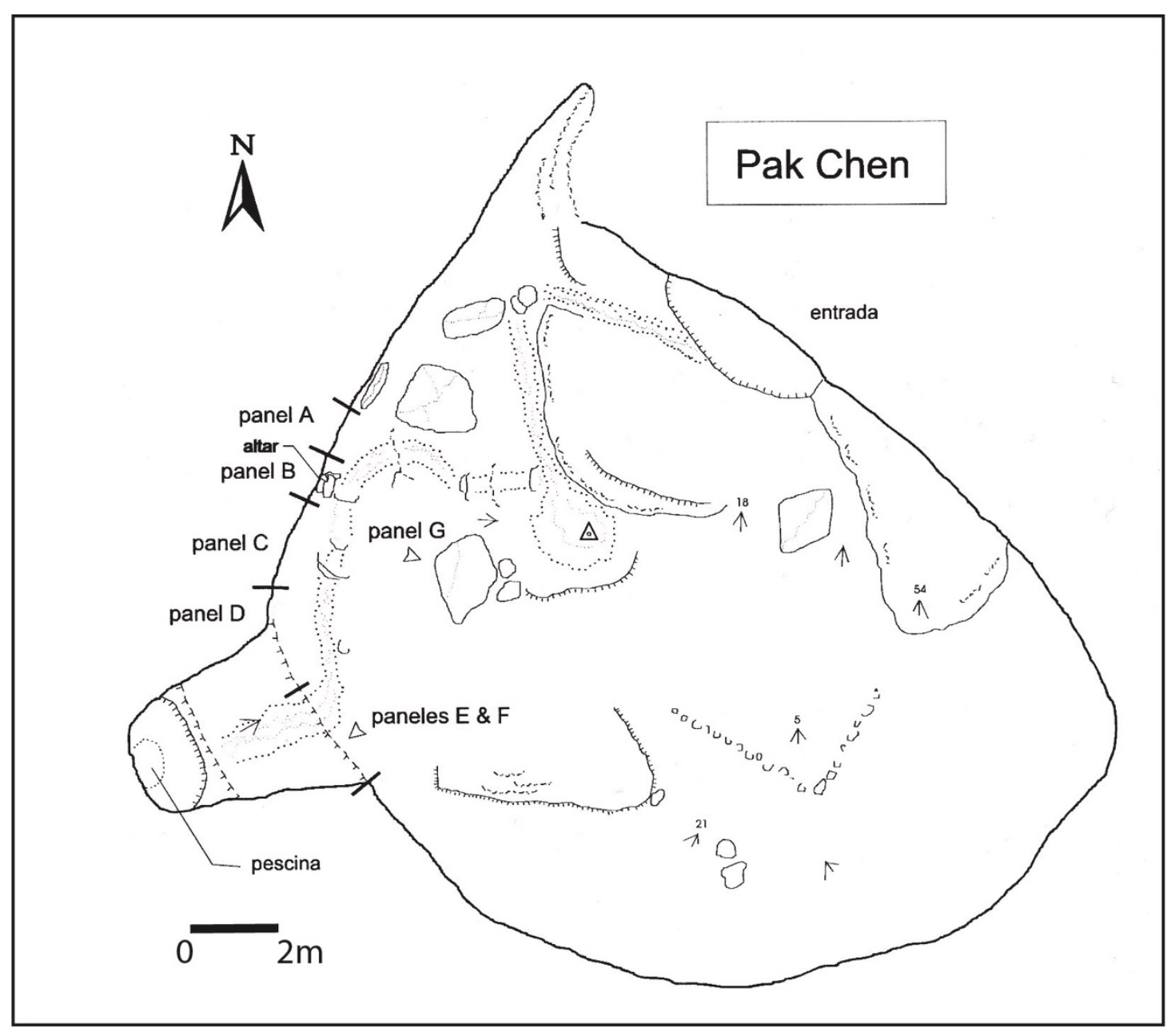

Figure 9. Map of Pak Ch'en, Quintana Roo, adapted from [15] (Figure 4.5.1). 


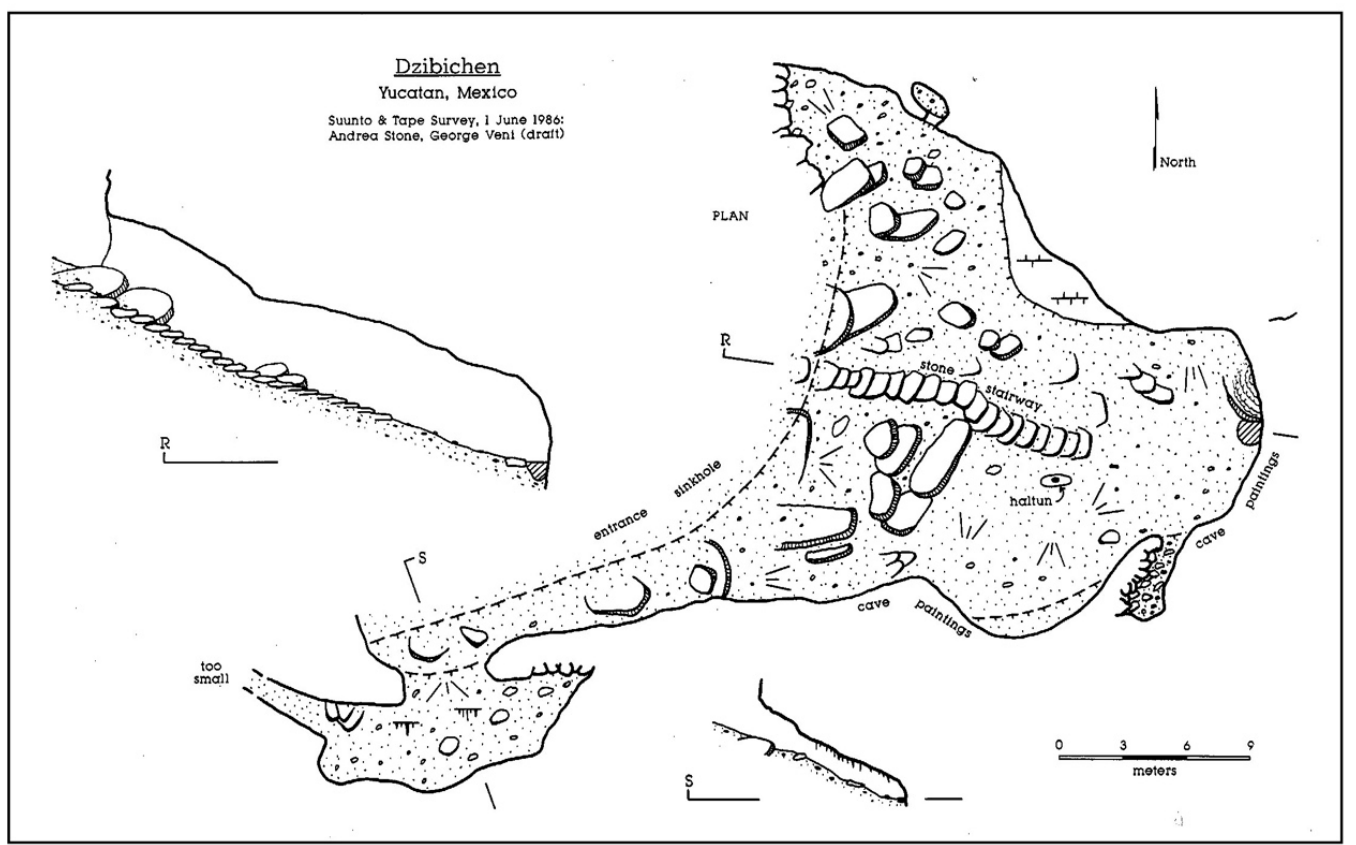

Figure 10. Map of Dzibichen, Yucatan, after [2] (Figures 4-65).

\section{Sexual Imagery}

Strecker [57] offers the first significant discussion of sexual imagery within the corpus of Maya rock art. In this work, he brings into question visually graphic scenes from Naj Tunich (Guatemala) that are thought to depict the act of genital bloodletting [2,58-60]. His alternative autoerotic interpretations (which emphasize the concept of fertility over sacrifice) were met with much debate [1,60,61] (pp. 90-94); nevertheless, he notes that blood from the penis was likely imbued with generative powers. In Stone's commentary to Strecker's article, she asserts that there are "vague boundaries that separate themes of fertility/sexuality and sacrifice in Maya thought and art" [61] (p. 37). Brady [60] (p. 54) echoes this sentiment and adds that the sexual connotation of caves "embraced both the aspect of eroticism and fertility."

In addition to phallic imagery from caves, Strecker [57] discusses and cites the occurrence of several vulva depictions. Such representations of female genitalia, often characterized by a triangle with a vertical slit, are found elsewhere in Mesoamerica (e.g., Chalcatzingo [62]) and may reflect the widespread association of caves with feminine attributes. Brady [60] provides detailed examples from Mesoamerican myths, as well as ethnographic accounts, that clearly attest to the cave as the womb of the earth—which, furthermore, may account for the invoking of such imagery in the cave environment. Perhaps more germane to our discussion here is the spatial association of certain female sexual imagery with watery areas in caves.

Of the several reports of vulva motifs from caves in the northern lowlands, few provide detailed contextual information. A well-known female image from Loltún, one of several painted figures on the walls of Room 3, is located in the same chamber as thirty-nine haltunob $[2,63]$ (p. 60). This simple painting is a variation on the vulva motif in which an exaggerated, inverted U-shaped element is shown between the legs of an anthropomorphic figure [63] (p. 4); [1] (Figure 10); [2] (Figures 4-31); [64] (p. 82). A similar example is illustrated by Sayther et al. [10] (Figure 14) in Actun Kaua. This extensive maze cave is known for its impressive galleries of mud drawings [10,65,66]. Sayther et al. [10] (p. 97) describe a large cave pool surrounded by pictographs and note that residents of the town of Kaua had ready access to water via open cenotes. It is then conceivable that the water deep inside the labyrinth of Actun Kaua would have taken on a special meaning. A similar situation is discussed by Rissolo [15] (pp. 129-131) in Actun Pech. Though not associated with a cave pool, what appears to 
be a more naturalistic representation of a vulva was carved on the ceiling of Aktun Kuruxtun [36] (p. 609; Figure 5.13). On the walls of Dzibichen, a complete human figure combines the U-shaped motif with the vertical slit and is located on the same panel as at least three discrete vulva motifs [2] (pp. 74-86); [64] (pp. 82,92). Dzibichen, along with Pak Ch'en, provides the strongest recorded evidence of the contextual relationship between female sexual imagery and cave water.

As mentioned above, the stairway into Dzibichen leads to a pool, while the walls of the small main chamber are adorned with drawn and painted images [2] (pp. 74-75). Vulva motifs, combined with the serpents and a codex-style Chaak figure, create an environment in which rain/water and fertility were clearly emphasized. In Pak Ch'en [15] (pp. 62-71), at least ten carved vulva motifs surround the rain god image (Figure 6a), while numerous others are found along the pathway to the pool. Perhaps most striking is a large, highly naturalistic carved rendering of a vulva, which is located directly above the pool in Pak Ch'en [15] (Figure 4.5.16). It appears that this image was intended to mark the pool as a watery and womb-like place, and the sacred epicenter of the cave.

It is also interesting to note that sexual imagery has been recorded on the walls of chultunob in the Puuc region of Yucatan [50,51]. Of the two human figures that adorn the chultun at Sayil, one is clearly a female with spread legs and the other, though also in a similar pose, is more sexually ambiguous [50] (Figures 3b,c); [51] (Figure 32). A stuccoed phallus was also found in a chultun at Xkichmook [51] (Figure 31). Returning to Actun Kaua, a prominent pictograph of an anthropomorphic figure displays an erect penis [10] (Figure 14); [65] (Figure 9). Tec Pool, who refers to the cave as Aktun $\mathrm{K}^{\prime} \mathrm{ab}$, describes the scene has having a fertility theme [65].

A petroglyph depicting a frontal figure with an enlarged phallus can be found in a watery chamber-known originally as Group-Y Cave and later as Cueva de Punta Piedra-north of the Postclassic Maya port site of Xcaret [67] (pp. 49-50); [21] (pp. 108-113); [68]. The figure is located on an outcrop flanking a masonry shrine (Figure 11a,b). The shrine faces an entrance to the rather extensive cave and is characterized by a stuccoed façade (with traces of paint) and a collapsed stone slab roof. The figure's body is rudimentary in form, with greater emphasis on the penis and testicles. The simple circular face in the tableau has been interpreted as either the figure's own face [67] (p. 50) or an adornment of sorts on the figure's waist [21] (p. 109), with the figure's torso, arms, and indistinguishable face positioned above. Andrews and Andrews [67] speculated that this upper region of the petroglyph might depict a headdress or a separate figure. Uncontested, however, is the prominence of the pubic region. The shrine and flanking carved outcrop effectively create an offertory or performative space while channeling access to the adjacent cave pool.

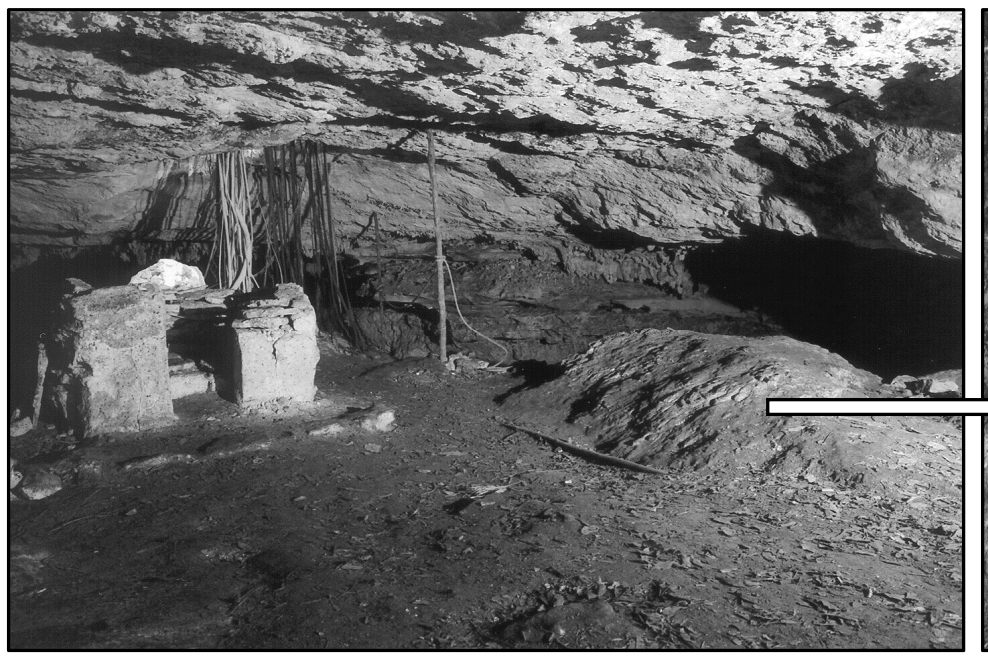

(a)

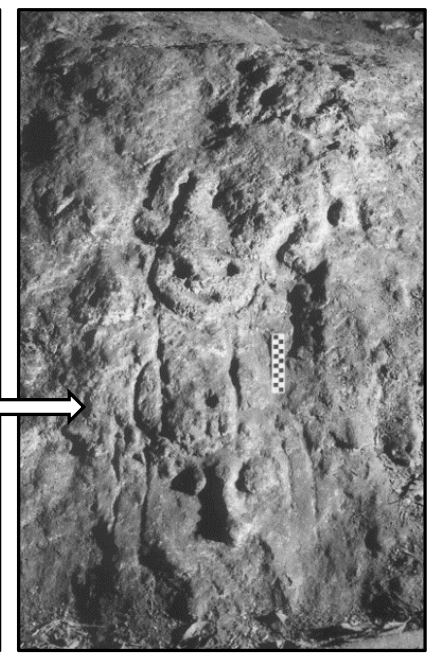

(b)

Figure 11. Xcaret Group-Y Cave (also known as Cueva de Punta Piedra): (a) Shrine; bedrock mound to right with petroglyph of male figure (photo by D. Rissolo); (b) petroglyph (photo by D. Rissolo). 
As a final comment on sexual cave art in the northern Maya lowlands, it appears as if depictions of phalli are not necessarily associated with water with the same frequency as vulva motifs. With the exception of the painted captive in Actun Ch'on [6], the meaning of phallic images-within the general concepts of fertility and sacrifice - might be more closely related to the generative and life-sustaining powers of blood from the penis, rather than the more watery connotations of female genitalia.

\section{Concluding Thoughts}

The role or meaning of a cave is more than the sum of its constituent elements. It is the interrelationship between natural and cultural phenomena. Indeed, it is the interplay between surface and subterranean, light and dark, wet and dry, near and remote. The images painted and carved on walls of caves were part of this ideological complex. Across the northern Yucatan Peninsula, watery caves witnessed the rites and rituals of religious practitioners who appealed to the gods of rain-beseeching the Chaaks to ensure agricultural abundance. Early explorers and scholars have long noted the solemnity of the act and the fortitude and determination of resident Maya who undertook these subterranean journeys [69,70].

Dunning et al. [71] convincingly cast the cave at Xcoch as "home of the rain gods" and the realm of the ancient ones compelled to propitiate them. Indeed, the need to assert control over water (physically and spiritually) was essential to the Maya of the Puuc region of Yucatan. At Xcoch, a long and winding passageway descends deep beneath the civic-ceremonial site center. The sheer abundance of offertory detritus - broken pottery, charcoal—attests to the cave's symbolic role as well as the ritual appropriation of this route to the precious water below [71].

Ringle et al. [72] note that on Puuc stelae, rulers are sometimes depicted as having a connection with the Chaaks. This powerful iconographic association supports an interpretation of the larger regional rock art corpus as one preoccupied with the themes of water and fertility. Ongoing rock art documentation efforts and comparative studies will enhance our understanding of how the Maya of the northern lowlands conceptualized, engaged, and interacted with underground worlds and contribute to the valorization of Mexico's subterranean heritage.

Funding: Funding for research included in this study was provided by the National Speleological Society, Cave Research Foundation, Quintana Roo Speleological Survey, Anders Foundation, and the Strauss Family Fund for Mesoamerican Studies. Technical and logistical support was provided by the Centro Investigador del Sistema Acuífero de Quintana Roo, AC (CINDAQ).

Acknowledgments: I would like to thank the communities of Naranjal, San Juan de Dios, and Kantunilkin (Quintana Roo, Mexico), as well as Lorenzo Ancona Díaz de León and Jorge Portillo, for granting access to the caves included in this study. Permission to conduct field research was granted by the National Institute of Anthropology and History (INAH) and was graciously facilitated by Adriana Velázquez Morlet and María José Con. Documentation was accomplished with the assistance of Fred Devos, Sam Meacham, Fabio Esteban Amador, Kurt Heidelberg, and Jorge Cab Canul. I appreciate the support and involvement of the following individuals: Zoë Abrahams, Stephen Alvarez, Miguel Astor-Aguilera, Alfredo Barrera Rubio, Jim Coke, Miguel Covarrubias, Scott Fedick, Jeffrey Glover, Kevin Hovey, Zac Hruby, Marcia Kirby, Falko Kuester, Luis Alberto Martos López, Jennifer Mathews, Carmen Rojas, Peter Sprouse, Brian Strauss, and Enrique Terrones. A very special thank-you to James Brady, Andrea Stone, and Karl Taube for their insight, mentorship, and intellectual generosity. This study is dedicated to the memories of Luis Leira Guillermo and Bil Phillips, who devoted their lives to the exploration and conservation of the cultural and natural heritage of Quintana Roo.

Conflicts of Interest: The author declares no conflict of interest.

\section{References}

1. Bonor Villarejo, J.L. Las Cuevas Mayas: Simbolismo y Ritual; Universidad Compultense de Madrid: Madrid, Spain, 1989.

2. Stone, A. Images from the Underworld: Naj Tunich and the Tradition of Maya Cave Painting; University of Texas Press: Austin, USA, 1995.

3. Stone, A. Regional Variation in Maya Cave Art. J. Cave Karst Stud. 1997, 59, 33-42. 
4. Thompson, E.H. Cave of Loltun; Memoirs of the Peabody Museum of American Archaeology and Ethnology; Harvard University: Cambridge, MA, USA, 1897; Volume 1.

5. Stone, A. The Painted Walls of Xibalba: Maya Cave Painting as Evidence of Cave Ritual. In Word and Image in Maya Culture: Explorations in Language, Writing, and Representation; Hanks, W.F., Rice, D.S., Eds.; University of Utah Press: Salt Lake City, UT, USA, 1989; pp. 319-335.

6. Stone, A. Actun Ch'on, Oxkutzcab, Yucatán: Una Cueva Maya con Pinturas del Clásico Tardío. Bol. Esc. Cienc. Antropol. Univ. Yucatán 1989, 16, 24-35.

7. Strecker, M. Cuevas Mayas en el Municipio de Oxkutzcab, Yucatán (I): Cuevas Mis y Petroglifos. Bol. Esc. Cienc. Antropol. Univ. Yucatán 1984, 68, 21-28.

8. Barrera Rubio, A.; Peraza Lope, C. Los vestigios pictóricos de la cueva de Tixcuytún, Yucatán. In Land of the Turkey and the Deer: Recent Research in Yucatan; Gubler, R., Ed.; Labyrinthos: Lancaster, CA, USA, 1999; pp. 37-56.

9. Tec Pool, F.; Krempel, G. The Paintings of Aktun Santuario, Akil, Yucatan. Mexicon 2016, 38, 97-107.

10. Sayther, T.; Stuart, D.; Cobb, A. Pictographic Rock Art in Actun Kaua, Yucatan, Mexico. Am. Indian Rock Art 1998, 22, 95-102.

11. Strecker, M. Cuevas Mayas en el Municipio de Oxkutzcab, Yucatán (II): Cuevas Ehbis, Xcosmil, y Cahum. Bol. Esc. Cienc. Antropol. Univ. Yucatán 1985, 70, 16-21.

12. Bonor Villarejo, J.L. Exploraciones en las Grutas de Calcehtok y Oxkintok, Yucatán, México. Mayab 1987, 33, 24-31.

13. Uc González, E.; Canche Mazanero, E. Calcehtok desde la Perspectiva Arqueológica. In Memorias del Segundo Coloquio Internacional de Mayistas; Universidad Nacional Autónoma de México: Mexico, 1989; pp. 287-301.

14. Bonor Villarejo, J.L.; Sánchez y Pinto, I. Las Cavernas del Municipio de Oxkutzkab, Yucatán, México: Nuevas Aportaciones. Mayab 1991, 7, 36-52.

15. Rissolo, D. Ancient Maya Cave Use in the Yalahau Region, Northern Quintana Roo, Mexico, Bulletin 12; Association for Mexican Cave Studies: Austin, TX, USA, 2003.

16. Miller, A.G. (Ed.) On the Edge of the Sea: Mural Painting at Tancah-Tulum, Quintana Roo, Mexico; Dumbarton Oaks: Washington, DC, USA, 1982.

17. Rissolo, D. Beneath the Yalahau: Emerging Patterns of Ancient Maya Ritual Cave Use from Northern Quintana Roo, Mexico. In In the Maw of the Earth Monster: Mesoamerican Ritual Cave Use; Brady, J.E., Prufer, K.M., Eds.; University of Texas Press: Austin, TX, USA, 2005; pp. 342-372.

18. Martos López, L.A. Investigaciones en la Costa Oriental: Punta Venado y La Rosita, Quintana Roo. Arqueología 1994, 11-12, 71-93.

19. Martos López, L.A. La Cueva de Aktunkoot, La Rosita, Quintana Roo; Informe de los trabajos de mapeo y exploración de la temporada 1992 y 1993 del Proyecto Arqueológico Calica; INAH: Mexico City, Mexico, 1994.

20. Martos López, L.A. Por las Tierras Mayas de Oriente: Arqueología en el Área de Calica; Calica-INAH: Mexico City, Mexico, 2002.

21. Martos Lopez, L.A. Cuevas de la Region Central-Oriental de la Peninsula de Yucatan: Un Analisis desde la Perspectiva Simbolica. Ph.D. Thesis, Escuela Nacional de Antropologia e Historia, Mexico City, Mexico, 2010.

22. Lothrop, S.K. Tulum: An Archaeological Study of the East Coast of Yucatán; Publication 335; Carnegie Institution of Washington: Washington, D.C., USA, 1924.

23. de Robina, R. Estudio Preliminar de las Ruinas de Hochob, Municipio de Hopelchen, Campeche; Editorial Atenea: Mexico City, Mexico, 1956.

24. Rissolo, D. Tancah Cave Revisited. AMCS Act. Newsl. 2005, 28, 78-82.

25. Houston, S.D. Classic Maya Depictions of the Built Environment. In Function and Meaning in Classic Maya Architecture; Houston, S.D., Ed.; Dumbarton Oaks Research Library and Collection: Washington, DC, USA, 1998; pp. 333-372.

26. Grove, D.C. Miscellaneous Bedrock and Boulder Carvings. In Ancient Chalcatzingo; Grove, D.C., Ed.; University of Texas Press: Austin, TX, USA, 1987; pp. 159-170.

27. Broda, J. Lenguaje Visual de Paisaje Ritual de la Cuenca de México. In Códices y Documentos Sobre México 2nd Simposio; Rueda, S., Vega, C., Martínez Baracs, R., Eds.; Colección Científica del INAH: Mexico City, Mexico, 1997; Volume II, pp. 129-162.

28. Rissolo, D. Maya Cave Shrines along the Central Quintana Roo Coast. AMCS Act. Newsl. 2004, 27, 57-59. 
29. Devos, F.; CINDAQ, Puerto Aventuras, Quintana Roo, Mexico City, Mexico. Personal Communication, 14 August 2020.

30. Strecker, M. Representaciones de manos y pies en el arte rupestre de cuevas de Oxkutzcab, Yucatán. Bol. Esc. Cienc. Antropol. Univ. Yucatán 1982, 52, 47-57.

31. Tec Pool, F. Distribución y Contexto de las Pictografías en Kanun Ch'en, Homún, Yucatán. Mundos Subterráneos 2012, 22-23, 13-20.

32. Rissolo, D. El Arte Rupestre de Quintana Roo. In Arte Rupestre de México Oriental y Centro América; Künne, M., Strecker, M., Eds.; Indiana Beihefte. Gebr. Mann Verlag: Berlin, Germany, 2003; Volume 16, pp. 79-96.

33. Moyes, H. Constructing the Underworld: The Built Environment in Ancient Mesoamerican Caves. In Heart of Earth: Studies in Maya Ritual Cave Use; Bulletin Series No. 23; Brady, J.E., Ed.; Association for Mexican Cave Studies: Austin, TX, USA, 2012; pp. 95-110.

34. Rissolo, D.; Hess, M.R.; Hoff, A.R.; Meyer, D.; Amador, F.E.; Velazquez Morlet, A.; Petrovic, V.; Kuester, F. Imaging and Visualizing Maya Cave Shrines in Northern Quintana Roo, Mexico. In Proceedings of the 8th International Congress on Archaeology, Computer Graphics, Cultural Heritage and Innovation, Valencia, Spain, 5-7 September 2016; Editorial Universitat Politecnica de Valencia: Valencia, Spain, 2016; pp. 382-384.

35. Rissolo, D.; Lo, E.; Hess, M.R.; Meyer, D.E.; Amador, F.E. Digital Preservation of Ancient Maya Cave Architecture: Recent Field Efforts in Quintana Roo, Mexico. Int. Arch. Photogramm. Remote Sens. Spat. Inf. Sci. 2017, XLII-2/W5, 613-616.

36. Slater, D.A. Into the Heart of the Turtle: Caves, Ritual, and Power in Ancient Central Yucatan, Mexico. Ph.D. Thesis, Brandeis University, Waltham, MA, USA, 2014.

37. Moyes, H.; Awe, J.J. Belize Regional Cave Project: Report of the 2015 Field Season; National Institute of Culture and History: Belmopan, Belize, 2016.

38. Helmke, C.G.B.; Awe, J.J. Preliminary Analysis of the Pictographs, Petroglyphs, and Sculptures of Actun Uayazba Kab, Cayo District, Belize. In The Western Belize Regional Cave Project: A Report of the 1997 Field Season; Department of Anthropology Occasional Paper No. 1; Awe, J.J., Ed.; University of New Hampshire: Durham, NH, USA, 1998; pp. 141-199.

39. Helmke, C.G.B.; Awe, J.J.; Griffith, C.S. El Arte Rupestre de Belice. In Arte Rupestre de México Oriental y Centro América; Künne, M., Strecker, M., Eds.; Indiana Beihefte. Gebr. Mann Verlag: Berlin, Germany, 2003; Volume 16, pp. 111-131.

40. Moyes, H.; University of California, Merced, Merced, CA, USA. Personal Communication, 13 September 2020.

41. Astor-Aguilera, M.; Arizona State University, Tempe, AZ, USA. Personal Communication, 2 March 2001.

42. Houston, S.D.; Stuart, D. T632 as Muyal, “Cloud.”. Cent. Tennessean Notes Maya Epigr No.1. 1990.

43. Stone, A. The Cleveland Plaque: Cloudy Places of the Maya Realm. In VIII Palenque Round Table 1993; Robertson, M.G., Macri, M., McHargue, J., Eds.; Pre-Columbian Art Research Institute: San Francisco, CA, USA, 1996; pp. 403-412.

44. Reilly, F.K., III. The Lazy-S: A Formative Period Iconographic Loan to Maya Hieroglyphic Writing. In VIII Palenque Round Table 1993; Robertson, M.G., Macri, M., McHargue, J., Eds.; Pre-Columbian Art Research Institute: San Francisco, CA, USA, 1996; pp. 413-424.

45. Villacorta, C.J.A.; Villacorta, C.A. Codices Mayas; Tipografía Nacional: Guatemala City, Guatemala, 1976.

46. Angulo, V.J. The Chalcatzingo Reliefs: An Iconographic Analysis. In Ancient Chalcatzingo; Grove, D.C., Ed.; University of Texas Press: Austin, TX, USA, 1987; pp. 132-158.

47. Villela, F.S.L. Nuevo Testimonio Rupestre Olmeca en el Oriente de Guerrero. Arqueología 1989, 2, 37-48.

48. Barrera Rubio, A. The Rain Cult of the Puuc Area. In Fourth Palenque Round Table, 1980; Palenque Round Table Series 4; Benson, E.P., Ed.; Pre-Columbian Art Research Institute: San Francisco, CA, USA, 1985; pp. $249-260$.

49. Barrera Rubio, A. Obras Hidraulicas en la Region Puuc, Yucatán, México. Bol. Esc. Cienc. Antropol. Univ. Yucatán 1987, 15, 3-19.

50. Zapata Peraza, R.L. El Uso del Agua y los Mayas Antiguos: Algunos Ejemplos Arqueológicos de Campeche. Bol. Esc. Cienc. Antropol. Univ. Yucatán 1987, 15, 20-31.

51. Zapata Peraza, R.L. Los Chultunes: Sistemas de Capitación de Agua Pluvial; Instituto Nacional de Antropología e Historia: Mexico City, Mexico, 1989.

52. Spranz, B. Descubrimiento en Totimehuacan, Puebla. Boletin Del INAH 1967, 28, 19-22. 
53. Manzanilla, L. The Construction of the Underworld in Central Mexico: Transformations from the Classic to the Postclassic. In Mesoamerica's Classic Heritage: From Teotihuacan to the Aztecs; Carrasco, D., Jones, L., Sessions, S., Eds.; University Press of Colorado: Boulder, CO, USA, 2000; pp. 87-116.

54. Taube, K.A. The Major Gods of Ancient Yucatan; Studies in Pre-Columbian Art and Archaeology, No. 32; Dumbarton Oaks Research Library and Collection: Washington, DC, USA, 1992.

55. Strecker, M.; Stone, A. El Arte Rupestre de Yucatán y Campeche. In Arte Rupestre de México Oriental y Centro América; Indiana Beihefte; Künne, M., Strecker, M., Eds.; Gebr. Mann Verlag: Berlin, Germany, 2003; Volume 16, pp. 76-91.

56. Taube, K.A.; University of California, Riverside, Riverside, CA, USA. Personal Communication, 1 June 1999.

57. Strecker, M. Representaciones Sexuales en el Arte Rupestre de la Región Maya. Mexicon 1987, 9, 34-37.

58. Brady, J.E.; Stone, A. Naj Tunich: Entrance to the Maya Underworld. Archaeology 1986, 39, 18-25.

59. Stone, A. The Moon Goddess at Naj Tunich. Mexicon 1985, 7, 23-29.

60. Brady, J.E. The Sexual Connotation of Caves in Mesoamerican Ideology. Mexicon 1988, 10, 51.

61. Stone, A. Commentary. Mexicon 1987, 9, 37.

62. Apostolides, A. Chalcatzingo Painted Art. In Ancient Chalcatzingo; Grove, D.C., Ed.; University of Texas Press: Austin, TX, USA, 1987; pp. 171-199.

63. Strecker, M. Pinturas Rupestres de la Cueva de Loltún. Boletín Del INAH. 1976, 18, 3-8.

64. Velázquez Morlet, A.; López de la Rosa, E.; Casado López, M.; del P. Gaxiola, M. Zonas Arqueológicas: Yucatán; Instituto Nacional de Antropología e Historia: Mexico City, Mexico, 1988.

65. Tec Pool, F. Representaciones pictográficas en la cueva de Aktun K'ab, en Kahua, Yucatán. In XXII Simposio de Investigaciones Arqueológicas en Guatemala, Guatemala City, Guatemala, 21-25 July 2008; Laporte, J.P., Arroyo, B., Mejía, H., Eds.; Museo Nacional de Arqueología y Etnología: Guatemala City, Guatemala, 2009; pp. 1328-1342.

66. Veni, G. The Mayan Maze of Actun Kaua. AMCS Act. Newsl. 2003, 26, 65-68.

67. Andrews, E.W., IV; Andrews, A.P. A Preliminary Study of the Ruins of Xcaret, Quintana Roo, Mexico: With Notes on Other Archaeological Remains on the Central East Coast of the Yucatán Peninsula; Publication 40; Middle American Research Institute: New Orleans, LA, USA, 1975.

68. Terrones, E.; Leira, L. Plano de la Cueva Grupo Y de Xcaret, Proyecto Punta Piedra; Archivo del Centro INAH Quintana Roo: Chetumal, Mexico, 1984.

69. Andrews IV, E.W. Balankanche, Throne of the Tiger Priest; Publication 32; Middle American Research Institute: New Orleans, LA, USA, 1970.

70. Stephens, J.L. Incidents of Travel in Yucatan; Harper and Rowe: New York, NY, USA, 1843.

71. Dunning, N.P.; Weaver, E.; Smyth, M.P.; Ortegón Zapata, D. Xcoch: Home of Ancient Maya Rain Gods and Water Managers. In The Archaeology of Yucatan; Stanton, T.W., Ed.; Archaeopress: Oxford, UK, 2014; pp. $65-80$.

72. Ringle, W.M.; Bey, G.J., III; Gallareta Negrón, T. A New Monument from Huntichmul, Yucatan, Mexico, Research Reports on Ancient Maya Writing No. 57; Boundary End Archaeological Research Center: Barnardsville, NC, USA, 2009.

(C) 2020 by the author. Licensee MDPI, Basel, Switzerland. This article is an open access article distributed under the terms and conditions of the Creative Commons Attribution (CC BY) license (http://creativecommons.org/licenses/by/4.0/). 